\title{
Interpreting the Motif of The Son from America from the Historical Perspective
}

\author{
Xin HUANG \\ Department of English Language and Literature, School of Foreign Languages and Literature, \\ Wuhan University, Wuhan, China
}

229047453@qq.com

Keywords: Issac Bashevis Singer, The Son From America, Jewish History, Cultural Identification.

\begin{abstract}
As an American Jewish writer with great reputation, Issac Bashevis Singer has published a number of novels and short story collections, always adhering to the Jewish characteristics in his writing which reveals Jews' tragic destiny. The Son from America, one of Singer's best-known short stories, vividly depicts the lives of Eastern European Jews before WWI and is typical of Singer's writing style. This paper aims at interpreting the motif of The Son from America from the historical perspective, analyzing the old and young Jews' attitudes towards their tradition respectively. The study finds that although Berl and Bercha differ from their son in lifestyle and sociocultural context, they all stick to Jewish values and doctrines, reflecting their in-depth consensus on cherishing Jewish culture. This paper is somewhat original given scanty previous studies on the short story.
\end{abstract}

\section{Introduction}

\section{Issac Bashevis Singer and His Works}

Issac Bashevis Singer, the winner of the 1978 Nobel Prize in Literature, is a representative American Jewish writer. As a leading figure in the Yiddish literary movement, Singer always insists on writing and publishing works solely in Yiddish. His novels and short stories usually depict the Eastern European Jewish community where he has once lived. The theme of betrayal and return of Jewish culture runs through his writing career [1]. His writing style is characterized by combining realistic techniques and fantasies of supernatural descriptions. Singer's works mainly reflect the strong Jewish character and indicate the diversity of American literature as well.

Singer's representative novels include The Family Moskat (1950), The Magician of Lublin (1960), The Slaw (1692), etc. He has also published some successful short story collections such as Gimpel the Fool and Other Stories and A Crown of Features and Other Stories. The Son from America is one of Singer's best short stories, set in a small village in Poland before WWI. It is a story about cultural shock and root seeking in the Jewish community. The story echoes with Singer's personal experiences and presents a sharp contrast of attitudes between generations who all adamantly uphold their Jewish culture and custom.

\section{Literary Review}

In the western literary circle, studies on Issac Bashevis Singer became popular after Singer won the Nobel Prize in Literature in 1978. Comments on Singer usually got polarized because of different cultural backgrounds. Leonard Kriegel spoke highly of Singer's literary achievement, especially his Yiddish writing. He appraised that "it was Singer who would embody for the literary world the voice of the destroyed shtetl among the Yiddish writers" [2]. By contrast, other critics did not attach such importance to Singer's works. For example, Zaritt expressed the suspicion for Singer's literary status, claiming that "Singer encountered an undecidability in trying to compensate for the linguistic uncertainty of Yiddish in the transnational and translational US landscape" [3].

In China, studies on Singer sprang up in the 1980s since he won the the 1978 Nobel Prize in Literature. Many mainstream literary magazines introduced Singer's biography and works, enabling 
Chinese readers to know the famous American Jewish writer. However, the studies seemed to be transient because domestic scholars paid more attention to other modernist writers such as Franz Kafka and James Joyce under the influence of the modern context [4]. It was not until the $21^{\text {st }}$ century that the research on Singer achieved great breakthroughs for the literary circle realized the uniqueness in Singer's works. Many of his works were reintroduced and translated into different versions, providing a new perspective for Chinese literary creation [4].

\section{Analysis of the Motif from the Historical Perspective}

\section{Crisis of Jewish People}

Jews have been living in exile ever since the Babylonian Captivity that deprives them of a peaceful and stable homeland. "Banished from the land of Israel by God, Jews live dispersed among the nations, subordinate in political authority" [5]. Considerable Jewish literary works thus aim at revealing the racial discrimination of and oppression on Jews [6], however, Singer does not present that history directly but through details in the short story The Son from America. The group of Jews in the story live the exiled life in the small village of Lentshin in Poland, and many of their descendants choose to leave the tranquil village for their better development.

\section{Exiling Jews}

Seemingly secluded from the outside world, the village is preserved to be pristine and villagers are self-sufficient by running small farms. The old couple, Berl and Berlcha, lead a quite simple but happy life in Lentshin. They are satisfied with their frugal life, enjoying the harmony with animals and nature. However, it is hard to believe that Berl, Berlcha and many other villagers are living in exile. Before they settle in Lentshin, they have suffered much from the political turmoil and expulsion.

Expelled from his previous settlement in Russia, Old Berl has to start life again in Poland. His tragedy reflects the common misery the Jews underwent as they were forced by the Russian Government to leave the country. With the competition and friction between Jews and Russians being ever intense, the Russian government started to promote anti-Semitism nationwide to deport Jews [7]. The wide range of anti-Semitism causes permanent traumatic consequences on both the personal and the collective levels, doing much harm to the diaspora [8].

Admittedly, Jews are tough and strong-willed because they soon restart their new lives in different places whatever predicaments they are faced with. Though without a fixed homeland, Jews take root in every part of the world and never stop endeavoring to rebuild their lost homeland. In the small village, the diaspora are still concerned about the survival of Jewish people. The Zionist movement is also reflected in the story - "A heretic by the name of Dr. Herzl had come up with the idea that Jews should settle again in Palestine" [9]. Theodor Herzl, the founder of the political Zionist movement, led a large number of Jews to return to their homeland Palestine [10]. Berl and Berlcha are those zealous Jews believing they can return to their homeland eventually. Though in exile, Jews are dedicated to reviving their nation, be they the leaders or the masses. They have encountered incomparable difficulties and humiliation, but they always embrace the same faith that they will reunite as a country one day.

\section{Immigration to Other Countries}

Before WWI, the world was undergoing the groundbreaking technical innovation that changed almost every aspect of human society. Yet, hardly has the village been influenced by the scientific inventions, instead they still keep the traditional pastoral style. The isolation of the small village endows the diaspora temporary stability, protecting them against war and deportation. Nevertheless, the new crisis emerges that they have difficulty in continuing the Jewish tradition there for many of their descendants immigrate to other places or countries.

The story is set before World War I, a period when abundant changes took place, both technically and politically. At that time, the US attracted immigrants from all over the world because it was 
considered as a land of opportunity and every one could pursue his or her American dream there. In the story, Samuel had lived in America for forty years and succeeded in becoming a millionaire [9]. Samuel also made it to settle in America and his offspring grew up with Christian names [9].

Like Samuel, there are many other villagers making a living elsewhere. "Lentshin became a village with few young people who had left for Zakroczym, for Nowy Dwor Warsaw, and sometimes for the United States" [9]. Without young men, the Jewish tradition is hard to be preserved in the village. The death of the old generation can probably foresee the decline of Jewish culture if more young men move out. Entering a new country, immigrants have been marginalized as they must get acquainted with the exotic ethos that blurs their original identities [9]. The immigration brings about cultural shock and Jewish immigrants have to adapt to foreign cultures in a new country, which will naturally shake the status of Jewish ethos.

\section{Identification with Jewish History}

As aforementioned, the Jews in the story live in an abyss of misery where they are homeless and vulnerable. Exiling Jews flit from one exotic country to another just for fleeing from the political persecution. They also face the new challenge that more young men tend to move out of the Jewish community, which threatens the continuity of Jewish culture. However, what is more salient in the short story is the acknowledgment of their culture. Both the old and the new generation show sincere reverence to their history and tradition. The Jewish identity is embodied through "behaving in ways that are grounded in Jewish practice, community, or heritage" [11].

\section{Berl's and Berlcha's Identification and Preservation}

As the representatives of the old generation in the Jewish village, Berl and Berlcha are the firm defenders of Jewish culture and custom. On one hand, they try to maintain their old lifestyle and alienate themselves from modern civilization or exotic culture. They are indifferent to any forms of scientific inventions such as kerosene lamp and cable, not wishing any changes for the status quo. They may seem conservative and rigid to abide by the traditional rules in their culture. For example, only when Samuel returned did Berl call Berlcha by her given name "Percha". It was believed that the young or those from the big cities would call a wife by her name [9]. From these details, readers may discern that the old Jews highly identify themselves with their tradition and custom.

On the other hand, Berl and Berlcha attach great importance to the traditional Jewish custom of observing Sabbath. The day is set for Jews to have a rest after a week's hard work, and family members will gather together to enjoy the family dinner. On every Friday, the old couple will prepare for the Sabbath in the traditional way. Sabbath is such an important and solemn day for them that they are busy preparing the dinner all day. Only for the Sabbath would Berlcha buy three tallow candles and some flour in the store [9]. When their son Samuel returned, it happened to be the Sabbath day. Even in the moment or reunion, Berlcha could not rest because she had to "make a larger Sabbath stew with such a guest" [9]. Having heard the news of Samuel's return, some women volunteered to help Berlcha with the dinner [9]. The traditional custom binds the Jewish community together and witnesses the cohesion of Jewish people. These points reflect that the old Jews in Lentshin both highly acknowledge and well preserve the traditional Jewish custom. In addition, the neighbors' hospitality shows the virtue of mutual help in Jewish tradition.

\section{Samuel's Identification and Adaptation}

To some extent, Samuel represents the young Jewish generation who have been somewhat influenced by foreign cultures. Samuel's return brings about the sharp contrast of attitudes and lifestyles between two generations. Overall, in spite of the great changes, Samuel still identifies himself with his cultural root and tries to adapt to the traditional environment after coming back.

Forty years outside cannot remove the deep impacts of Jewish culture on Samuel and he keeps in mind the traditional Jewish tenets. Samuel was only fifteen years old when he left home and had lived in the US for forty years. When he returned, he still spoke in Yiddish, though his parents could not 
understand him well at first [9]. It can be extrapolated that Samuel must have spoken Yiddish a lot in America or he can hardly communicate with his parents. In addition, Samuel chooses to return on the Sabbath day because he knows what the day means to Jews, and he would like to surprise his parents on the special day. Samuel remembers the Sabbath taboos firmly. For example, he remembered that smoking was forbidden on the Sabbath [9]. Instead of betraying his cultural identity, Samuel holds fast to the Jewish custom and shows great respect for his own culture.

However, it is hard for Samuel to readjust to the traditional Jewish community since he has lived in America for such a long period. The great cultural shock makes the process of adaptation full of challenges. Hard as he tries, Samuel still has difficulty integrating into the former Jewish community thoroughly. It is obvious that Samuel differs with the original villagers in the clothing, manner, and thinking mode, etc. Take Samuel's clothing for example. The noble man wore a beaver hat, a cloak bordered with fur and a solid-gold watch chain, completely contrary to those of his parents [7]. In addition, Samuel is not accustomed to the pace of life in Lentshin at first. Everything seems to be so tranquil and slow in the small village while Samuel, the outsider, cannot get used to it after living in New York for forty years. Anyhow, Samuel is determined to return to his cultural root but have to suffer from the cultural shock before he can integrate to the local community once again.

\section{Conclusion}

The Son from America is a concise but thought-provoking short story, which exemplifies Jew's affection for and adherence to their culture and religion. Singer being an influential Jewish writer, the short story epitomizes part of his life before World War I, presenting to readers an adamant people with incredible fidelity.

This paper is aimed at interpreting the motif of the short story from the historical perspective. Though Jews are faced with the predicament of exile and immigration, the old generation still stick to Jewish tradition and custom. On one hand, they never forget their history and mission. On the other hand, capable of adjusting themselves to various circumstances, they are content with what they have already had, inheriting their Jewish culture as well. Even the young generation who scatter all around the world inherit and develop Jewish tradition, ensuring the continuity of Jewish culture.

\section{References}

[1] A. Cheng, X. Zheng, On the Motifs of Issac Bashevis Singer's Novels, Foreign Literature. 5(2001) 57-64.

[2] L. Kriegel, This World and That Shtetl: The Short Fiction of Isaac Bashevis Singer, Sewanee Review. 2(2005) 332-337.

[3] S. N. Zaritt, Maybe for Millions, Maybe for Nobody: Jewish American Writing and the Undecidability of World Literature, American Literary History. 3(2016) 542-573.

[4] X. Wei, Research on Isaac Bashevis Singer in China, News Lovers. 4(2012) 80-81.

[5] J. E. Cooper, A Diasporic Critique of Diasporism: The Question of Jewish Political Agency, Political Theory. 1(2015) 80-110.

[6] Y. Huang, On the Distinctive Motive of Jewish Literature in Singer's Novels, Changchun University of Technology (social sciences edition). 1(2005) 79-80.

[7] Y. Guo, A Brief Analysis of the Historical Evolution of Russia's Policy for the Jews, Siberian Studies. 6(2015) 78-84.

[8] R. Tamar, L. Edna, H, Angelika, Recollection and Relocation in Immigration: Russian-Jewish Immigrants "Normalize" Their Anti-Semitic Experiences, Symbolic Interaction, 2(2002) 175-198. 
[9] D. Wu, Aesthetics of American Literature, Shanghai Foreign Languages Education Press, Shanghai, 2009.

[10] J. Yu, Interpreting the emergence of Zionism (1882-1914), West Asia and Africa. 4(1997) 36-43.

[11] H. Hartman, M. Hartman, Jewish Identity and the Secular Achievements of American Jewish Men and Women, Journal for the Scientific Study of Religion. 1(2011) 133-153. 